\title{
Animeldelse:
}

\section{Den lille bestyrerinde - Stalins datter Svetlana}

\author{
Jan Jakob S. Floryan
}

At læse Rosemary Sullivans Stalins datter er at følge to spor, der bliver ved med at krydse hinanden. Man får et eminent indblik $i$ sider og aspekter af denne mordets gigant $o g$ hans skygge, der forfulgte Svetlana livet igennem, som den forfølger Rusland.

Sullivan, Rosemary: Stalins datter.

Svetlana Alliljevas utrolige og turbulente liv. Informations Forlag, 2015. 599 s.

Svetlana Josefitjova Stalina var hendes fulde navn: Fornavn, fadersnavn og efternavn, og det sidste definerede samtidig hendes livs drama. Født i 1926 som datter af den 25-årige mor, Nadja (Nadesjda - Håb), og den 46-årige Josef Visarionovitj Djugasjvili, med dæknavnet Stalin. Nadja var hans anden hustru. Svetlanas første år var lykkelige i det lyse, rummelige og ovenud charmerende tidligere adelige landsted Sobolevo omkring $40 \mathrm{~km}$ fra Moskva, som var stillet til rådighed for Stalin i kraft af hans allerede dengang høje embeder og ikke mindst tætte forbindelse til Vladimir Lenin. På landstedet oplevede Svetlana frihed til leg, oplevelse og samvær med sin mors, Allilujev'ernes, familie.

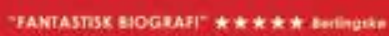

STALINS DATTER

SVETLANA ALULUJEVAS UTROLIGE OG TURBULENTE LIV

ROSEMARY SULLIVAN

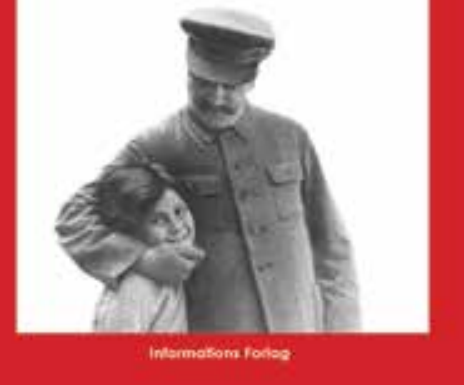

Det var så meget anderledes end vinterlejligheden i Potjesjin-paladset i Kreml. Her havde Stalin sammen med andre topledere fået tildelt en passende bolig i det tidligere Lystslot, der også havde huset et teater. I anden halvdel af det 19. årh. flyttede imidlertid - ganske passende for den vigtigste, senere beboer Stalin - zarens Okhrana, Beskyttelse, dvs. det hemmelige politi, ind. I paladset havde hun sin barne-

Jan Jakob S. Floryan er cand.scient.pol. \& art.; mangeårig DR-korrespondent bl.a. i Rusland 
pige og en husholderske at være sammen med, men også sin noget fjerne mor. Besynderligt nok var det hendes far, der stod for den tætte kontakt med datteren og gav hende den kærlighed, hun tragtede efter i det omfang han havde tid til det.

\section{Stalins øjesten}

Svetlana var hans øjesten. Af første ægteskab havde han to sønner og en datter. Den ene af sønnerne, Jakov, begik selvmord i tysk krigsfangelejr efter at hans far havde afslået et tysk forslag om at udveksle ham for feltmarskal von Paulus, der var blevet taget til fange i Stalingrad (senere Volgograd). Med Nadja havde han inden Svetlana fået sønnen Vasja (Vasilij). Det tætte forhold kom til udryk i, at denne selvhersker over Alrusland (zarernes titel) kaldte hende sin lille Sveta (Svetlana) 'værtinde' eller 'husbestyrerinde', mens hans selv betegnede sig i brevene som 'din ynkværdige sekretær, den fattige bonde J. Stalin'. Hun kaldte ham sin 'førstesekretær' (det var han også i partiet), og andre af rigets mægtigste mænd, medlemmer af Politbureauet, gav hun også numre som sekretærer. Således var Anastas Mikojan, der senere spillede en rolle for hende efter Stalins død, 'sekretær nr. 4'. Kommunikationen mellem datter og far og de øvrige 'sekretærer' foregik via små sedler med beskeder. Hun kunne fx skrive, hvad hun ønskede sig - farveblyanter, en blok, en bamse - og bestillingen blev straks effektueret. Da hun var 6-7 år citerer hun sin far for at have sagt: "Du skal ikke bede om noget, du skal befale". Resten af sit liv blev hun noget sarkastisk kaldt 'Kreml-prinsessen', selv da hendes privatliv lå i ruiner og økonomi ditto.

Det ubekymrede barneliv fik en brat ende, da hendes mor Nadja begik selvmord i 1932. Det hed sig officielt og i fa- milien, at der var tale om bughindebetændelse. Først senere læste Svetlana i et amerikansk blad i forbindelse med sin engelskundervisning, at morens død var selvmord. Hun spurgte sig for hos sin mormor og fik det bekræftet. Den eneste gang Stalin nævnte hendes mors bortgang for Svetlana var, da hun var teenager og det på en årsdag for morens død. Han sagde ringeagtende, at hun havde brugt en 'legetøjspistol' af meget ringe kaliber. Men effektiv nok. Morens selvmord forvandt Svetlana aldrig. Hun følte sig svigtet af hende og nu næsten udleveret til sig selv, især da faren trak sig længere og længere væk fra hende. Det bidrog også til ændringen i stemningen i Svetlanas barndomsår, at Stalin efter Nadjas selvmord opgav landstedet Sobolevo og i 1934 fik bygget et landsted efter sit eget hoved i Kuntsevo 25 km fra Moskva, 'den nære datja' - mørk, indelukket og dyster.

\section{En verden af rædsel, angst $\mathrm{og}$ terror} At læse Rosemary Sullivans Stalins datter er at følge to spor, der bliver ved med at krydse hinanden. Man får et eminent indblik i sider og aspekter af denne mordets gigant og hans skygge, der forfulgte Svetlana livet igennem, som den forfølger Rusland. Det første spor er den absurde verden af rædsel, angst og terror, der herskede omkring Stalin, og som han selv havde skabt og udbredt til det ganske russiske land. Som lille havde Svetlana ingen anelse om, hvad der foregik omkring hende. Hun undrede sig dog over, hvorfor nogle af 'sekretærerne' eller 'onklerne', som de også blev kaldt, pludselig forvandt for ikke at vende tilbage, og ingen nævnte det med ét ord. Endnu mere foruroligende blev det, da også medlemmer af familien pludselig gled ud af billedet, og også her var der ingen informationer at 
fa. Svetlana kom imidlertid videre med sit liv. Hun gk i Mønsterskole Nr. 25 sammen med andre af den højeste elites børn. De blev bragt og hentet i regeringslimousiner, og der var indrettet et venterum for deres livvagter. Her blev der ikke talt om andre emner end undervisningen, men pludselig kunne en dreng eller en pige dukke op og tude hele dagen igennem, og få dage senere kom han ikke.

Svetlana ville gerne læse litteraturvidenskab, men beskeden om det affødte et raserianfald hos Stalin. Hun skulle ikke blande sig med disse bohemer, narcisister og dagdriverter. Lige efter krigsafslutningen fremstod USA stadig som en venligtsindet allieret, og som kompromis med faren fik Svetlana lov til at hellige sig amerikanske studier på universitetet.

Hér og dér får man i biografien et blik ind i Stalins politiske tænkning, som Svetlana ellers ikke ruttede med at udbrede. Midt under krigen med Tyskland sagde han engang $i$ hendes påhør "sammen havde vi været uovervindelige". Det var med tanke på pagten med Hitler fra august 1939, da de to socialismer indgik en gensidigt udbytterig alliance på det politiske og økonomiske plan.

Som 16-årig blev Svetlana forelsket i den væsentligt ældre og gifte filmmand Aleksej Kapler. Han var jøde, og Stalin var ikke begejstret for affæren og satte sin sikkerhedschef general Vlasik på sagen. Kapler forsvandt for en femårig periode. Til Svetlana hvæsede Stalin om ham 'engelsk spion'. Omkring studentereksamen begyndte Svetlanas bevidsthed at undergå en radikal forandring. Hun fandt ud af, at hendes far VAR STATEN. Hans almagt blev åbenlys for hende. Det blev en til tider ubærlig byrde i resten af hendes liv. Det stod pludselig klart for hende, hvorfor 'sekretærerne' og 'onklerne' forsvandt fra
Stalins nærmeste kreds, og hvorfor medlemmer af familierne Alllujev og Svanidze (Stalins første hustru) også var væk. Hun kiggede længere væk fra sin nære familie, sine venner og ud i samfundet og genfandt samme mønster af uforklarlige forsvindinger. Det var alt sammen hendes fars værk.

Stalin døde i marts 1953, og Svetlana oplevede hans dødskamp og sidste gestus: En hævet knytnæve. Den kunne ses som en trussel eller en befaling, men ikke forsoning. Om ham dirrede det af frenetisk positionering og kampen om arven. I første omgang gik magten til chefen for NKVD, Lavrentij Berija. Tre måneder senere blev han henrettet. Som sikkerhedschef vidste han for meget om alle de andre.

I Svetlanas ikke ubegrundede opfattelse kom Berija til at fremstå som den umiddelbart skyldige i alle ulykkerne. Det var ham, der eksekverede Stalins ordrer.

I februar $1956 \mathrm{blev}$ hun ringet op af politbureaumedlem Mikojan ('sekretær nr. 4'), der bad hende aflægge sig et besøg. Her fik hun udleveret en tyk mappe med et maskinskrevet manuskript. "Læs det", sagde han og forlod biblioteket. De næste timer sad hun som naglet. Hun blev mere og mere rædselsslagen over indholdet.

Det var teksten til Nikita Khrusjtjovs 'hemmelige tale' til den 20. partikongres en uge senere. Her afslørede SUKP's generalsekretær hendes fars forbrydelser og glemte belejligt sin egen medvirken til dem. Talen tog fire timer på kongressen og næsten lige så lang tid for Svetlana at læse. Hun gik uden at sige farvel til Mikojan.

Det skulle nu blive officielt kendt for hele verden, hvad det var for en mand, der var hendes 'sekretær nr. 1', hendes papusjka, lillefar. 


\section{Svetlanas tragedie}

Det andet spor i biografien og Svetlanas liv er dets tragedie. Den evigt mislykkede jagt på en mand, der kunne forstå og udholde hendes skæbne. Det kunne ingen af dem, hun blev gift med, klare. For Kapler var forbindelsen én blandt mange affærer, for 16-årige Svetlana alvor. Den blev resolut afsluttet af Stalin. Næste i rækken var hendes første mand Grigorij Morozov, også en jøde med det oprindelige navn Moroz (Frost), russificeret for at skjule den jødiske herkomst. Den førnævnte general Vlasik kunne godkende ham og præsenterede ham som ulastelig kommunist for Stalin. De kunne blive gift. Ægteskabet varede ikke længe.

Næste mand var Jurij Sjdanov, hvis far havde været folkekommissær for kultur og berygtet for sin terror mod den kulturelle og intellektuelle elite. Det var helt efter bogen, men sluttede også brat. Den sidste sovjetiske mand var Ivan Svanidze fra Stalins første hustrus familie. Igen katastrofe. I begyndelsen af 1960erne mødte Svetlana, der nu længe havde ført navnet Allilujeva, en prins. Det var Brajes Singh, en yngre søn af rajien af Kalanakar i Uttar Pradesh. Han var kommunist, men også dødeligt syg, og var i Moskva for at få behandling. Samtidig fjernede han sig mere og mere fra kommunismen til fordel for humanismen. Svetlana fulgte med ham til sygehuset og var ved hans dødsleje.

Hun havde ikke fået lov til at gifte sig med ham (udlænding) og heller ikke besøge ham i Indien. Men besynderligt nok fik hun tilladelse til at rejse til Indien for at sprede hans aske i Ganges. Dermed sluttede hendes sovjetiske liv. I et kapitel som taget ud af John le Carrés spionromaner opsøgte hun den amerikanske ambassade i Dehli og bad om asyl. Dermed trådte Stalins datter ind på den storpolitiske sce- ne. Hun blev pludselig et anliggende for de to supermagter, men det var ikke som Svetlana Allilujeva, sovjetisk borger, men som Svetlana Stalina - datter af manden, der havde hersket over en sjettedel af verdenen.

Svetlanas tid i USA blev ingen dans på roser. Det blev igen til et ægteskab, med Wesley Peters, og en datter, Olga, men i samme forbindelse kom hun i kløerne på en sekt af arkitekter, der ville udvikle en ny form for arkitektur. Ægteskabet kostede hende resten af hendes tilbageværende formue.

Derefter boede hun i England, hvor Olga kom i skole, men i 1984 henvendte hun sig til den sovjetiske ambassade i London for at få lov til at vende tilbage. Det blev et statsligt organiseret triumftog, for det var det at få Stalins fortabte datter hjem. Efter nogen tid ville Svetlana ud igen, ikke mindst for sin meget angelsaksiske datter Olgas skyld. På det tidspunkt havde Mikhail Gorbatjov overtaget magten og havde så mange vanskeligheder at slås med, at Svetlana ikke figurerede højt på hans dagsorden. Hun fik udrejsetilladelse.

I USA fortsatte Svetlana sin nomadetilværelse, med flytninger hvert år i en stadig jagt på et blivende sted. Det fandt hun først til allersidst på et alderdomshjem, hvor hun døde af kræft 85 år gammel i 2011.

\section{Opgør med fortiden}

Svetlana kunne skrive og havde drømt om at blive forfatter. Det kunne den almægtige fader ikke tillade, men længe efter hans død skrev hun bogen Twenty Letters to a Friend (da. Svetlanas erindringer, Lademann, 1967). De blev, som det hed, 'skrevet til skuffen', for der kunne ikke blive tale om udgivelse i Sovjetunionen. Bogens 
tilblivelse gengives i biografien med alle de vanskeligheder, den indebar. Svetlana havde oplevet KGB's konfiskation af Vasilij Grosmans manuskript til Liv og skaeb$n e$. Hendes manuskript blev smuglet ud af den indiske ambassadør. Det er Svetlanas første sammenhængende opgør med sit ophav og sit liv, formet som breve til en ven. Vennen var en konkret person, men at nævne ham ved navn, ville være at sende ham i fængsel. For hun mente og fastholdt den opfattelse til det sidste, at trods alle omvæltningerne, personudskiftningerne og senere Sovjetunionens opløsning, forblev systemet det samme.

I bogen Only One Year (da. Således skete det, Grafisk Forlag 1978), som er en politisk analyse af sovjetsystemet, fremsætter hun tesen om, at terroren blev grundlagt af Lenin og blot ført til sin fuldkommenhed af hendes far. Sovjetunionen rasede, og de vestlige kommunister og sovjetsocialistiske klakører skruede voldsomt op for anklagerne om, at Svetlana var intet andet end en CIA-agent, og bogen var skrevet for hende af amerikanske efterretningsfolk.

Om Gorbatjov sagde Svetlana, at han var fuld af gode ideer og hensigter, men gav ham helt i begyndelsen af hans em- bedstid ingen chancer og fik ret. Tiden under Boris Jeltsin kaldte hun for 'tilnærmelsesvis demokrati', mens Vladimir Putin blot var en KGB-stud. Hans politik kaldte hun en genoplivning af stalinismen med nationalismen som den bærende idé. Hun talte videre om det russiske folks tragedie "for selv i dag (2010, red.) formår russerne ikke at føle sorg og anger for Stalins forbrydelser. Det lover ikke godt for fremtiden".

Rosemary Sullivans biografi af Svetlana Allilujeva er et videnskabeligt gennemarbejdet værk, der bygger ikke blot på offentlige arkiver, men også et utal af brevvekslinger med hendes veninder og med markante politiske og samfundsmæssige personligheder. Der er gennemført et utal af interviews med alle dem, der har kendt hende i Sovjetunionen, USA og England, og har ønsket at tale. Samtidig kan biografien læses som en sindsoprivende beretning om en skæbne, der savner sin lige.

Bogen er forsynet med stamtavler over familierne Djugasjvili/Stalin og Allilujev, med udførlige noter, oversigt over personerne, kildehenvisninger, omfangsrig litteraturliste og navneregister. 